\title{
DAMPAK TRANSPORTASI BERBASIS APLIKASI TERHADAP PENYERAPAN TENAGA KERJA DI KOTA SEMARANG
}

\section{IMPACT OF ONLINE TRANSPORTATION ON EMPLOYMENT SEMARANG CITY}

\author{
Anita Ratnasari Rakhmatulloh', Wido Prananing Tyas ${ }^{2}$, Muhammad Hendardi Subianto ${ }^{3}$ \\ 'Departemen Perencanaan Wilayah dan Kota, Universitas Diponegoro, Semarang; anita.ratnasari.r@gmail.com \\ 2Departemen Perencanaan Wilayah dan Kota, Universitas Diponegoro, Semarang; w.p.tyas@pwk.undip.ac.id \\ ${ }^{3}$ Departemen Perencanaan Wilayah dan Kota, Universitas Diponegoro, Semarang; hendardisubianto27@gmail.com \\ Info Artikel: \\ - Artikel Masuk: 11/10/2018 \\ - Artikel diterima: 08/11/2018 \\ - TersediaOnline: 02/01/2019
}

\begin{abstract}
ABSTRAK
Pesatnya perkembangan transportasi daring disebabkan oleh pelayanan transportasi publik yang belum mampu menjangkau seluruh wilayah di Kota Semarang. Selain itu, didukung dengan permintaan terhadap transportasi daring tinggi. Dalam beroperasi, transportasi daring ini membutuhkan operator sebagai pengemudi, kebutuhan pengemudi inilah yang memberikan peluang pekerjaan bagi masyarakat. Penelitian ini menggunakan metode analisis statistik deskriptif kuantitatif yang bertujuan untuk mengetahui dampak dari kehadiran transportasi daring terhadap penyerapan tenaga kerja.Metode analisis statistik deskriptif digunakan dalam hal penyajian data yang lebih informatif, seperti dalam penelitian ini yaitu menyajikan data tren perkembangan penyerapan tenaga kerja oleh perusahaan transportasi daring. Penyerapan tenaga kerja pada operator transportasi daring diharapkan dapat menyerap pengemudi ojek konvensional dan membuka lapangan kerja bagi yang belum mempunyai pekerjaan.Berdasarkan hasil penelitian, dari total keseluruhan jumlah pengemudi transportasi daring dapat menyerap dan mempekerjakan sebesar $2 \%$ tenaga kerja yang sebelumnya tidak memiliki pekerjaan. Tenaga kerja yang terserap sebagian besar adalah penduduk yang telah memiliki pekerjaan kemudian beralih untuk menjadi pengemudi transportasi daring.
\end{abstract}

Kata Kunci : Transportasi Daring, Dampak, Serapan Tenaga Kerja

\begin{abstract}
The rapid development of online transportation is caused by public transportation services that have not been able to reach all areas in the city of Semarang. In addition, it is supported by the demand for high online transportation. In operation, online transportation requires operators as drivers, this is the driver's needs that provide employment opportunities for the community. This study uses descriptive quantitative statistical analysis method which aims to determine the impact of the presence of online transportation on employment. Descriptive statistical analysis method is used in the presentation of more informative data, as in this study, which presents data on trends in the development of employment by online transportation companies. It is expected that labor absorption in online transportation operators can absorb conventional motorcycle taxi drivers and open employment opportunities for those who do not have jobs. Based on the results of the study, out of the total number of online transportation drivers can absorb and employ $2 \%$ of the workforce who previously did not have a job. The majority of workers absorbed are residents who already have jobs and then move on to become drivers of online transportation.
\end{abstract}

Keywords: Online Transportation, Impacts, Labor Absorption

Copyright $\odot 2018$ JPWK-UNDIP This open access article is distributed under aCreative Commons Attribution (CC-BY-NC-SA) 4.0 International license.

Cara men-sitasi (APA 6th Style):

Rakhmatulloh, Anita Ratnasari., Tyas, Wido Prananing \& Subianto, Muhammad Hendardi. (2018). Dampak Transportasi Berbasis Aplikasi Terhadap Penyerapan Tenaga Kerja Kota Semarang. Jurnal Pembangunan Wilayah dan Kota, vol 14, (4), 253-264 


\section{PENDAHULUAN}

Perkembangan teknologi menyebabkan kehadiran E-Commerce yang memanfaatkan teknologi internet sebagai sarana dalam berbisnis.Sektor transportasi menjadi sasaran dari E-Commerce. Kemajuan teknlologi ini sungguh tidak dapat diprediksi secara pasti, akan tetapi dampaknya sudah pasti secara signifikan dirasakan oleh berbagai bidang, termasuk di dalamnya bidang transportasi (Lyons and Davidson, 2016). Hal ini yang menjadi sebuah peluang besar bagi para pengusaha transportasi di Indonesia untuk dapat melakukan usahanya berbasis daring.Seringkali sarana transportasi yang disediakan oleh pemerintah tidak menjadi solusi bagi masyarakat.Di saat seperti ini transportasi daring muncul sebagai solusi dengan service yang dapat melayani masyarakat secara langsung. Sehingga pada akhirnya preferensi pengguna jasa transportasi, tentunya akan lebih memilih sebuah sistem transportasi yang mudah dan bersifat otomatis (Delle Site, Filippi and Giustiniani, 2011).

Transportasi daring melayani daerah-daerah dengan pusat aktivitas ekonomi tinggi dan memiliki kepadatan yang tinggi seperti daerah perkotaan (Hall,\& Krueger, 2016). Saat ini berkembang transportasi daring di Indonesia oleh 2 perusahaan yaitu Go-Jek dan Grab yang memiliki layanan di beberapa kotakota besar di Indonesia termasuk Kota Semarang. Tingginya penggunaan transportasi daring ini didasarkan pada efisiensi dan keamanan kepada pengguna jasa transportasi (Siuhi and Mwakalonge, 2016). Efisiensi dan keamanan ini merupakan faktor internal yang mempengaruhi perkembangan transportasi daring.Faktor internal merupakan faktor-faktor di dalamsistem yang mempengaruhi perkembangan dari transportasi daring.Transportasi akan tumbuh seiring dengan pertumbuhan aktivitas dan semakin luas area yang akan dilayani, gerakan yang lebih mudah digerakkan. Masalah seperti kemacetan dan masalah transportasi umum lainnya mulai muncul(Diah Intan dan Anita Ratnasari, 2018).

Kota Semarang adalah salah satu kota metropolitan, sehingga memiliki intensitas aktivitas dan permintaan perjalanan yang lebih tinggi. Permintaan perjalanan telah dilayani oleh transportasi umum tetapi layanan yang disediakan tidak efisien dalam hal biaya dan waktu(Rakhmatulloh et al., 2018). Hal ini berimplikasi terhadap kesiapan penyediaan sarana transportasi bagi masyarakat di Kota Semarang. Saat ini di Kota Semarang terdapat transportasi publik seperti Bus Rapid Transit dan angkutan dalam kota. Penyediaan transportasi publik ini seringkali tidak menjadi solusi bagi masyarakat dikarenakan transportasi publik yang ada saat ini memiliki service yang menganggap bahwa perjalanan yang dilakukan sebagai model agregat atau dapat dikatakan masyarakat yang melakukan perjalanan memiliki perilaku yang sama dengan tujuan yang hampir sama. Karena hal tersebut maka muncul transportasi daring yang cukup diminati masyarakat. Transportasi daring dianggap mampu memberikan pelayanan lebih dibandingkan transportasi umum seperti transportasi daring tidak terikat dengan rute dan jam pelayanan 24 jam. Karena cukup diminati dan jumlah permintaan terus mengalami peningkatan maka perusahaan transportasi daring membutuhkan operator untuk melayani penggunanya.

Kehadiran transportasi daring memberikan dampak terhadap penyerapan lapangan kerja.Transportasi daring mampu menghadirkan lapangan pekerjaan baru namun di sisi lain kehadiran transportasi daring menyebabkan masyarakat kehilangan lapangan pekerjaannya karena mengalami penurunan pendapatan seperti yang dialami oleh supir angkutan umum atau ojek konvensional. Berdasarkan fenomena tersebut menarik untuk diteliti yaitu pengaruh yang ditimbulkan dari keberadaan transportasi daring terhadap penyerapan tenaga kerja di Kota Semarang, khususnya bagi sopir angkutan umum dan ojek konvensional juga ikut terserap atau tidak dengan kehadiran transportasi daring di Kota Semarang, sehingga menjadi alternatif atau tambahan lapagan kerja yang tersedia di perkotaan. Penambahan lapangan kerja akan meningkatkan ekonomi kota.

Tujuan penelitian ini adalah untuk mengetahui pengaruh kehadiran transportasi daring terhadap penyerapan tenaga kerja di Kota Semarang. Untuk mencapai tujuan tersebut, ada beberapa sasaran yaitu menganalisis jenis layanan transportasi daring, karakteristik serapan tenaga kerja yang terserap oleh kehadiran transportasi daring, dan karakteristik operator yang terserap. Diharapkan dengan adanya penelitian dapat memberikan manfaat dalam hal pengembangan teori tentang fenomena perkembangan pada bidang transportasi khususnya aspek ketenagakerjaan. 


\section{Transportasi Daring}

Pelayanan transportasi daring, sama seperti pelayanan jasa transportasi pada umumnya. Perbedaannya terdapat beberapa keunggulan dari pelayanan jasa transportasi daring dibandingkan dengan transportasi konvensional. Pemilihan sistem yang lebih inovatif dan bersifat otomatis, akan dapat mempengaruhi preferensi pengguna jasa transportasi untuk lebih memilih transportasi daring (Delle Site dkk, 2011). Keunggulan sistem kerja yang terdapat pada transportasi daring yang bersifat inovatif yaitu dimana terdapat inovasi yang diberikan tidak seperti jasa layanan transportasi pada biasanya yang memberikan kemudahan bagi pengguna dengan memanfaatkan kemajuan teknologi seperti GPS yang memberikan titik lokasi driver sehingga pengguna diberikan kepastian.Selain itu inovasi yang terdapat pada transportasi daring ini yaitu fitur yang beragam tidak hanya antar jemput penumpang.Fitur yang diberikan ini seperti pembelian makanan, pengiriman barang, dan pengangkutan barang.

Transportasi erat kaitannya dengan pertumbuhan ekonomi pada sebuah kota. Kehadiran Transportasi daring, memiliki peran tersendiri dalam ekonomi kota. Untuk itu berikut ini kajian mengenai hubungan antara transportasi dan pertumbuhan ekonomi yang dikaji berdasarkan peran dan penerapan konsep ekonomi yang diterapkan oleh perusahaan transportasi daring.Dalam konteks perkotaan, transportasi memiliki peran penting sebagai penghubung setiap kegiatan manusia sehingga dapat dikatakan bahwa transportasi urat nadi kehidupan yang di dalamnya terdapat aspek ekonomi, sosial, politik, serta mobilitas penduduk (Kadir, 2006).

Sebelum penelitian ini dilakukan sudah ada penelitian yang dilakukan oleh Safrino pada tahun 2017. Dalam penelitiannya menjelaskan mengenai dampak kehadiran transportasi daring terhadap penyerapan tenaga kerja yang ada di Bogor dan tingkat kesejahteraan para driver transportasi daring. Kemudian perbedaan penelitian ini dengan penelitian sebelumnya yaitu penulis hanya membahas mengenai dampak penyerapan tenaga kerja di Kota Semarang. Selain itu, dalam penelitian ini juga ditambah dengan penjelasan mengenai karakteristik driver transportasi daring yang terserap dan persebaran driver transportasi daring di Kota Semarang yang disajikan dalam bentuk peta atau spasial.

\section{Karakteristik Ketenagakerjaan}

\section{a. Pengertian Tenaga Kerja}

Menurut Undang-Undang 13 Tahun 2003 Tentang Ketenagakerjaan, tenaga kerja adalah orangorang yang dapat melakukan sebuah aktivitas tertentu dalam rangka memenuhi kebutuhan sendiri ataupun kebutuhan masyarakat yang disebut dengan melakukan pekerjaan.Menurut Handoyo (2005), tenaga kerja terdiri atas angkatan kerja dan bukan angkatan kerja. Kelompok angkatan kerja atau Labor Force terdiri dari 2 golongan yaitu golongan yang bekerja dan golongan yang menganggur atau sedang mencari pekerjaan.Sedangkan bukan angkatan kerja terdiri dari golongan yang bersekolah, golongan yang sedang mengurus rumah tangga, dan golongan lainnya yang menerima pendapatan.

\section{b. Penawaran dan Permintaan Tenaga Kerja dalam Pasar Tenaga Kerja}

Tiga pihak yang terlibat yaitu pekerja, perusahaan, dan pemerintah dalam pasar tenaga kerja (Handoyo, 2005). Pemeran utama dari pasar tenaga kerja yakni pekerja, hal ini dikarenakan pekerja yang menentukan dirinya akan bekerja atau tidak, mencari keterampilan yang dibutuhkan, dan kapan akan memulai bekerja dan berhenti bekerja.Penawaran tenaga kerja akan meningkat apabila upah pada sebuah perusahaan tertentu juga meningkat. Dengan ini penawaran tenaga kerja dengan upah tenaga kerja memiliki hubungan yang berbanding lurus dan memiliki kurva slope positif.Pada sisi permintaan tenaga kerja yang sebagian besar dipengaruhi oleh perusahaan, akan memutuskan berapa banyak pekerjaan dan jenis pekerja yang akan dipekerjakan pada perusahaan. Perusahaan menginginkan upah yang minimum dengan jumlah pekerja yang maksimum.Tujuan perusahaan tersebut ingin memaksimalkan keuntungan dengan meminimalisir jumlah upah yang diberikan. Dalam hal ini dalam kurva permintaan tenaga kerja, upah tenaga kerja dengan jumlah pekerja memiliki hubungan yang berbanding terbalik atau memiliki kurva slope negatif. 
Penawaran dan permintaan tenaga kerja akan mencapai titik seimbang apabila kombinasi upah dan kesempatan kerja mencapai keseimbangan.Agar lebih mudahnya berikut kuva penawaran dan permintaan tenaga kerja yang membagi berdasarkan upah dan jumlah pekerja.Contoh mengenai kurva penawaran dan permintaan tenaga kerja dapat dilihat dalam Gambar 1.Pada kurva tersebut terlihat titik keseimbangan dimana dengan upah $\$ 40.000$ dengan 20.000 tenaga kerja yang dipekerjakan oleh perusahaan.Dalam mencapai titik keseimbangan ini juga diperlukan adanya peran pemerintah yang dalam hal ini memberlakukan pajak pada pendapatan pekerja, memberikam subsidi, menetapkan pajak pada perusahaan.

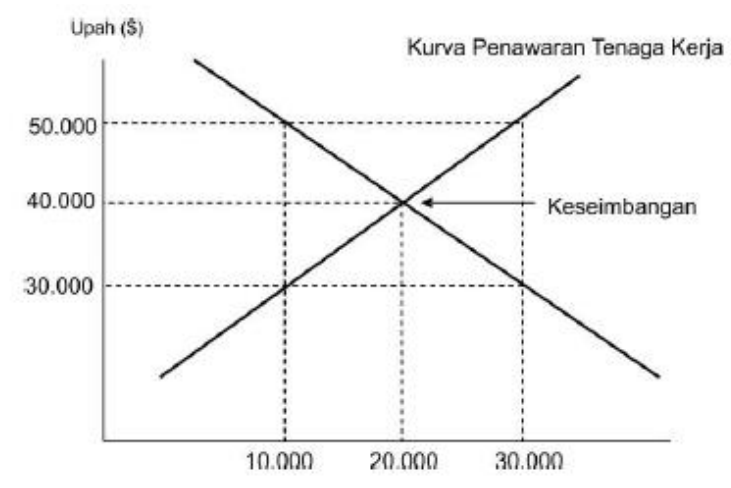

Gambar 1. Kurva Penawaran dan Permintaan Tenaga Kerja (Handoyo, 2005)

\section{DATA DAN METODE}

Penelitian ini menggunakan metode pendekatan kuantitatif dengan jenis penelitian berbasis observasi lapangan. Kemudian untuk alat analisisnya menggunakan statistik deskriptif (crosstab). Teknik pengumpulan data yang digunakan dalam penelitian ini antara lain pengumpulan data primer melalui wawancara, kuesioner, observasi lapangan, dan pengumpulan data sekunder melalui telaah dokumen dan literatur yang terkait dengan penelitian. Kemudian untuk teknik sampling yang digunakan adalah simple random sampling.

Penelitian ini menggunakan data rasio dan hipotesis asosiatif atau hipotesis yang menanyakan terkait dengan hubungan antar variabel. Kemudian untuk jenis data rasio dan hipotesis asosiatif maka menggunakan alat uji analisis statistik Metode Pearson. Sebelum dilakukan analisis dengan metode Pearson, terlebih dahulu dilakukan analisis elastisitas tenaga kerja terhadap kehadiran perusahaan transportasi daring. Berikut pengukuran elastisitas tenaga kerja (Safrino,2017).

$$
\text { Elastisitas Tenaga Kerja }=\frac{\text { Persetase Perubahan Jumlah Permintaan Tenaga Kerja }}{\text { Persentase Perubahan Jumlah TNC Ojek Online }}
$$

Berdasarkan rumus di atas, TNC yang dimaksud yaitu Transport Network Companies atau perusahaan transportasi daring.Apabila hasil perhitungan elastisitas tenaga kerja lebih besar dari satu $(>1)$, artinya laju permintaan tenaga kerja lebih besar dari laju pertumbuhn ojek daring sehingga kesempatan kerja menjadi bertambah. Kemudian setelah dilakukan analisis elastisitas ini dilakukan perhitungan Pearson dengan rumus sebagai berikut :

Dimana:

$$
r x y=\sqrt{\frac{\Sigma y-x}{\left(\Sigma x^{2}\right)\left(\Sigma x^{2}\right)}}
$$

$X^{2}=(X-C)^{2}$

$\mathrm{Y}^{2}=(\mathrm{Y}-\wedge)^{2}$

$\Sigma x y=$ jumlah hasil kali dari $x$ dan $y$ 
Keterangan:

1. Jika nilai $r(+)$ maka terdapat hubungan yang positif yang berarti kehadiran transportasi daring dapat meningkatkan permintaan tenaga kerja di Kota Semarang.

2. Jika nilai $r(-)$ maka kehadiran transportasi daring tidak mempengaruhi atau tidak diikuti dengan peningkatan permintaan tenaga kerja di Kota Semarang

Tahapan analisis dalam penelitian untuk mencapai tujuan penelitian antara lain:

1. Analisis karakteristik jenis layanan transportasi daring

Analisis ini digunakan untuk mengetahui gambaran jenis jenis layanan yang ditawarkan oleh perusahaan. Mengingat di Kota Semarang telah hadir 2 perusahaan besar transportasi daring yang masing-masing dari perusahaan tersebut bersaing untuk mencari konsumen dengan layanan yang inovatif. Untuk itu dalam analisis ini digunakan data karakteristik jenis layanan dari kedua perusahaan transportasi daring Sehingga output dari analisis ini yaitu berupa gambaran jenis layanan yang diberikan oleh perusahaan transportasi daring di Kota Semarang.

2. Analisis penyerapan tenaga kerja oleh perusahaan transportasi daring

Analisis penyerapan tenaga kerja pengemudi transportasi daring dilakukan untuk mengetahui penyerapan tenaga kerja serta karakteristik tenaga kerja yang bekerja sebagai pengemudi transportasi daring. Analisis penyerapan tenaga kerja pengemudi transportasi daring menggunakan jenis pekerjaan sebelum menjadi pengemudi transportasi daring, alamat domisili, latar belakang pendidikan, jenis kelamin, umur, tipe profesi, serta lama waktu kerja harian. Output dari analisis ini yaitu berupa gambaran mengenai penyerapan tenaga kerja pengemudi transportasi daring.

3. Analisis karakteristik pengemudi transportasi daring

Analisis karakteristik ini digunakan untuk mengetahui gambaran pengemudi transportasi daring di Kota Semarang. Yang dibahas dalam analisis ini yaitu kelompok umur, jenis kelamin, pendidikan, dan alasan memilih perusahaan transportasi daring dan persebaran daerah asal pekerja.

\section{HASIL DAN PEMBAHASAN}

\subsection{Analisis Karakteristik Jenis Layanan Transportasi Daring}

Jenis layanan transportasi daring terbagi menjadi dua yaitu layanan transportasi dan layanan non transportasi.

\section{a. Layanan Transportasi}

Layanan transportasi pada transportasi daring antara lain layanan antar jemput kendaraan roda dua dan roda empat, layanan pesan antar makanan, layanan pengiriman barang, layanan pembelian barang di toko, dan layanan pembelian tiket event. Layanan ini tersedia selama 24 jam setiap harinya.

b. Layanan Non Transportasi

Layanan non transportasi juga disediakan oleh perusahaan transportasi daring. Layanan tersebut antara lain layanan pembelian pulsa, layanan bengkel, layanan salon atau kecantikan, dan layanan jasa pijat, dan layanan membersihkan rumah.

\subsection{Analisis Penyerapan Tenaga Kerja Transportasi Daring}

Analisis penyerapan tenaga kerja antara lain terkait dengan jumlah tenaga kerja yang terserap, jenis pekerjaan tenaga kerja sebelum menjadi pengemudi, kelompok umur tenaga kerja yang terserap, latar belakang pendidikan tenaga kerja yang terserap, serta persebaran asal daerah tenaga kerja yang terserap.

\subsubsection{Jumlah Tenaga Kerja yang Terserap}

Kehadiran transportasi daring menimbulkan lapangan pekerjaan baru bagi masyarakat Kota Semarang. Berdasarkan data hasil wawancara, perkiraan jumlah pengemudi kendaraan roda 2 lebih banyak dibandingkan dengan jumlah pengemudi kendaraan roda 4 yaitu dengan total sejumlah 12.000 pengemudi transportasi daring.Pengemudi transportasi daring terbagi menjadi dua tipe yaitu sebagai 
pekerjaan utama dan sebagai pekerjaan sampingan. Pengemudi transportasi daring yang menjadikan pekerjaan utama sebesar $57 \%$ dan pekerjaan sampingan sebesar $43 \%$. Baik dari pengemudi yang menjadikan transportasi daring sebagai pekerjaan utama maupun sampingan tentunya memiliki pekerjaan sebelumnya (lihat Tabel 1.).

Tabel 1. Tipe Pekerjaan Driver Transportasi Daring (Hasil Survei, 2018)

\begin{tabular}{|l|l|r|}
\hline \multicolumn{1}{|c|}{ Tipe Pekerjaan } & $\begin{array}{c}\text { Jenis Pekerjaan } \\
\text { Sebelumnya }\end{array}$ & Jumlah \\
\hline \multirow{5}{*}{ Pekerjaan utama } & Security & 1 \\
\cline { 2 - 3 } & Swasta & 42 \\
\cline { 2 - 3 } & Wiraswasta & 11 \\
\hline & Tidak Bekerja & 2 \\
\cline { 2 - 3 } & Pengemudi & 1 \\
& angkot & \\
\hline \multirow{2}{*}{ Pekerjaan Sampingan } & Siswa/Mahasiswa & 9 \\
\hline & Penulis & 1 \\
\hline & Petani & 1 \\
\hline & PNS & 1 \\
\hline & Security & 2 \\
\hline & Serabutan & 1 \\
\hline & Swasta & 20 \\
\hline & Terapis & 1 \\
\hline & Wiraswasta & 7 \\
\hline
\end{tabular}

Berdasarkan Tabel 1.,pengemudi yang menjadi driver sebagai pekerjaan utama, awalnya bekerja sebagai security, swasta, wiraswasta, pengemudi angkot dan tidak bekerja. Terdapat $2 \%$ dari keseluruhan pengemudi transportasi daring yang tidak memiliki pekerjaan atau tergolong pengangguran sebelum memiliki profesi sebagai pengemudi transportasi daring. Artinya dalam sisi penyerapan pada tenaga kerja yang belum memiliki pekerjaan, transportasi memberikan dampak kecil.Kemudian sebagai pekerjaan sampingan, drivermemiliki pekerjaan utama sebagai mahasiswa, penulis, petani, PNS, security, swasta, terapis dan wiraswasta.

Jika dilihat berdasarkan Tabel 1., yang menjadi pekerjaan utama awalnya dari penduduk yang sudah memiliki pekerjaan sebelumnya. Karena dari pihak perusahaan transportasi daring memiliki syarat minimal untuk dapat menjadi operator atau driver transportasi daring. Syaratnya antara lain kepemilikan kendaraan atas nama pribadi, mempunyai KTP, SIM, STNK, SKCK, dan HP. Bagi penduduk yang sudah bekerja tentunya sudah memiliki syarat minimal tersebut, dibandingkan penduduk yang belum bekerja. Maka dari itu, penduduk yang terserap sebagai driver transportasi daring lebih banyak dari penduduk yang sudah bekerja dibandingkan penduduk yang belum atau tidak bekerja.

Pada tren penyerapan, dengan menggunakan data jumlah realisasi ijin operasional, dapat terlihat peningkatan penyerapan tenaga kerja yang bekerja pada angkutan transportasi daring (lihat Gambar 2).Tren penyerapan tenaga kerja menunjukan tren peningkatan tenaga kerja yang bekerja sebagai pengemudi angkutan transportasi daring setiap bulannya. Hal ini dapat menjelaskan lapangan pekerjaan baru sebagai pengemudi angkutan transportasi daring diminati oleh masyarakat Kota Semarang. Jumlah pengemudi yang selalu meningkat dan tidak dibatasi ini akandapat mempengaruhi pendapatan pengemudi sesuai dengan teori penawaran dan permintaan tenaga kerja. Semakin banyaknya jumlah pengemudi atau yang dalam hal ini adalah penawaran tenaga kerja maka pendapatan atau upah yang dibayarkan akan semakin sedikit atau dapat terjadi karena persaingan dalam pengemudi dengan pengemudi lain. 
Pengemudi transportasi daring yang menjadi responden dalam penelitian, $79 \%$ menjadi driver transportasi daring selama kurang dari 1 tahun. Kemudian 16\% selama 2 tahun dan 5\% selama 3 tahun. Jumlah pengemudi diperkirakan tersu mengalami peningkatan setiap tahunnya, namun pertambahan jumlah driver tersebut belum dilaporkan kepada pihak Dinas Perhubungan Kota Semarang. Maka dari itu, pihak pemerintah tidak dapat mengetahui tren penyerapan tenaga kerja secara riil. Pekerjaan sebagai pengemudi transportasi daring merupakan jenis lapangan pekerjaan baru sehingga pekerja yang berprofesi sebagai pengemudi transportasi memiliki pekerjaan sebelumnya.Dikarenakan pekerjaan sebagai pengemudi transportasi daring dapat dilakukan dengan fleksibel, profesi menjadi pengemudi transportasi daring ini juga membuat masyarakat untuk memilih pekerjaan ini sebagai pekerjaan sampingan.Profesi menjadi pengemudi transportasi daring banyak diminati karena memiliki waktu kerja yang fleksibel dibandingkan pekerjaan utama ataupun pekerjaan sampingan yang dimiliki.Hal tersebut dilihat dari total 100 orang responden, $80 \%$ memilih alasan menjadi pengemudi transportasi daring memiliki waktu kerja yang fleksibel.

Gambar 2.Penyerapan Tenaga Kerja Transportasi Daring (Dinas Perhubungan Kota Semarang, 2018)

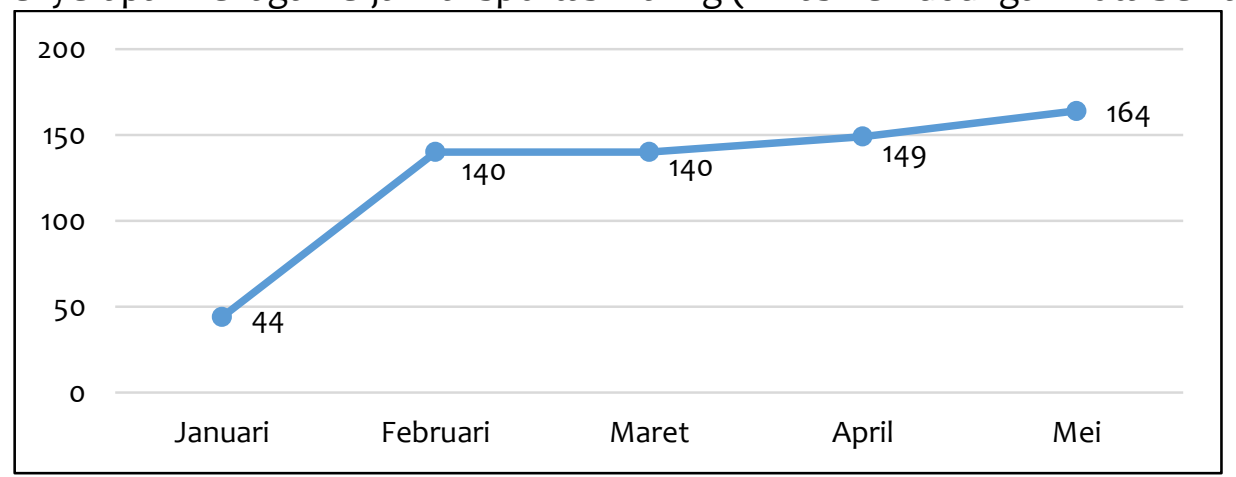

\subsection{Karakteristik Pengemudi Transportasi Daring}

\subsubsection{Kelompok Umur}

Kelompok umur yang banyak terserap yaitu pada kelompok umur 26-30 tahun dengan jumlah 21 orang. Kemudian untuk kelompok umur selanjutnya yang banyak memilih menjadi profesi pengemudi transportasi daring yaitu kelompok umur $\leq 25$ tahun dengan jumlah 20 orang. Selengkapnya lihat Gambar 3. Hal ini memperlihatkan bahwa pada kelompok umur tersebut sebagian masih tergolong ke dalam jenjang usia pelajar sebagai siswa ataupun mahasiswa. Untuk kelompok umur berikutnya hingga kelompok umur tertinggi yaitu $\geq 46$, pekerjaan sebelum menjadi pengemudi transportasi daring yang mendominasi yaitu swasta. 


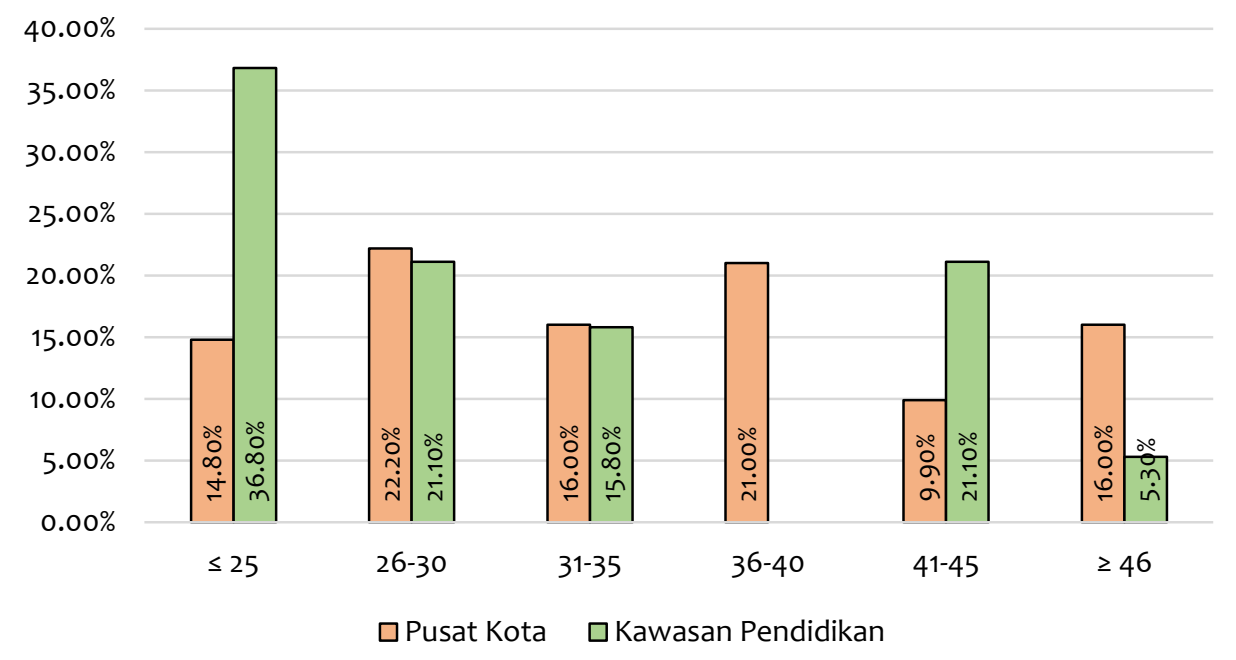

Gambar 3. Kelompok Umur Pengemudi Transportasi Daring(hasil survei, 2018)

\subsubsection{Pendidikan}

Latar belakang pendidikan bukan menjadi persyaratan sebuah pendaftaran menjadi pengemudi transportasi daring pada perusahaan.Berdasarkan hal ini dapat diketahui bahwa latar belakang pendidikan ini dapat berkaitan dengan pendidikan terakhir yang dimiliki oleh pengemudi transportasi daring.Selengkapnya lihat Gambar 4.

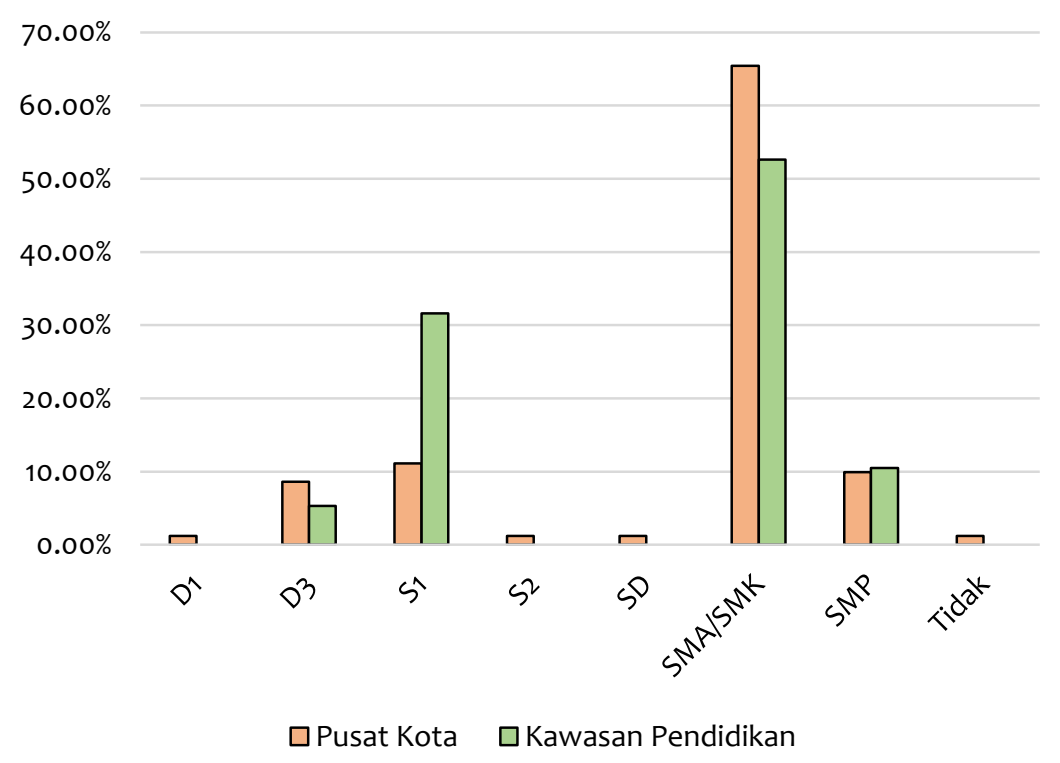

Gambar 4. Pendidikan Terakhir Pengemudi Transportasi Daring (Hasil Survei,2018)

Dapat diketahui bahwa driver transportasi daring di Kota Semarang didominasi oleh lulusan SMA/SMK. Perusahaan transportasi daring memiliki kecendrungan kesamaan latar belakang apabila dilihat berdasarkan jenis transportasi yang digunakan. Melalui perusahaan transportasi daring diketahui pengemudi yang mengemudikan kendaraan roda empat memiliki tingkat pendidikan yang lebih tinggi dibandingkan dengan pengemudi yang mengemudikan kendaraan roda dua.Berdasarkan hasil survei yang telah dilakukan, driver transportasi daring roda empat ada yang berlatar belakang pendidikan magister. Sedangkan driver transportasi daring roda empat didominasi oleh lulusan SMP dan SMA/SMK. 


\subsubsection{Jenis Kelamin}

Pengemudi atau driver transportasi daring di Kota Semarang didominasi oleh pria. Hal ini sesuai dengan survei yang telah dilakukan oleh peneliti. Hasil survei menunjukkan bahwa $99 \%$ dari driver transportasi daring merupakan pria dan sisanya adalah wanita. Ketika penulis melakukan survei cukup banyak driver transportasi daring berjenis kelamin pria yang menunggu pesanan di pinggir jalan. Sedangkan yang berjenis kelamin wanita jarang terlihat menunggu pesanan di pinggir jalan. Maka dari itu, sebagian besar responden berjenis kelamin pria.

\subsubsection{Alasan Memilih Perusahaan}

Berdasarkan hasil survei yang telah dilakukan, sebesar $80 \%$ dari pengemudi transportasi daring memilih menjadi driver dikarenakan waktu kerja yang fleksibel. Kemudian sebesar $11 \%$ karena mencari tambahan penghasilan dan 9\% karena pendapatan yang besar. Pekerjaan sebagai pengemudi transportasi daring dapat dijadikan pekerjaan sampingan karena tidak terikat dengan jam kerja. Baik dari perusahaan Go-Jek maupun Grab, minat masyarakat untuk menjadi driver tetap tinggi. Karena kedua perusahaan transportasi daring sama-sama memberlakukan sistem bonus bagi drivernya. Sistem bonus berdasarkan seberapa banyak poin yang dapat dikumpulkan oleh driver. Driver akan mendapatkan satu poin ketika driver memberikan layanan pengantaran (ride) dan mendapatkan dua poin ketika driver memberikan layanan makanan. Pemberian sistem bonus cukup menguntungkan bagi driver karena mendapatkan tambahan pendapatan.

\subsubsection{Persebaran Asal Daerah Tenaga Kerja}

Persebaran ruang pengemudi diketahui dengan melihat asal tempat tinggal pengemudi.Persebaran ruang pengemudi transportasi daring di Kota Semarang menyebar pada seluruh 16 kecamatan. Pengemudi transportasi daring banyak terdapat pada Kecamatan Banyumanik dan Kecamatan Semarang Timur. Hal ini tentu juga berkaitan dengan penggunaan lahan dan jumlah penduduk usia kerja yang ada pada wilayah tersebut. Penggunaan lahan sebagai permukiman dan banyaknya jumlah usia kerja akan menentukan intensitas jumlah pengemudi pada daerah tersebut. Selengkapnya lihat Gambar 5.

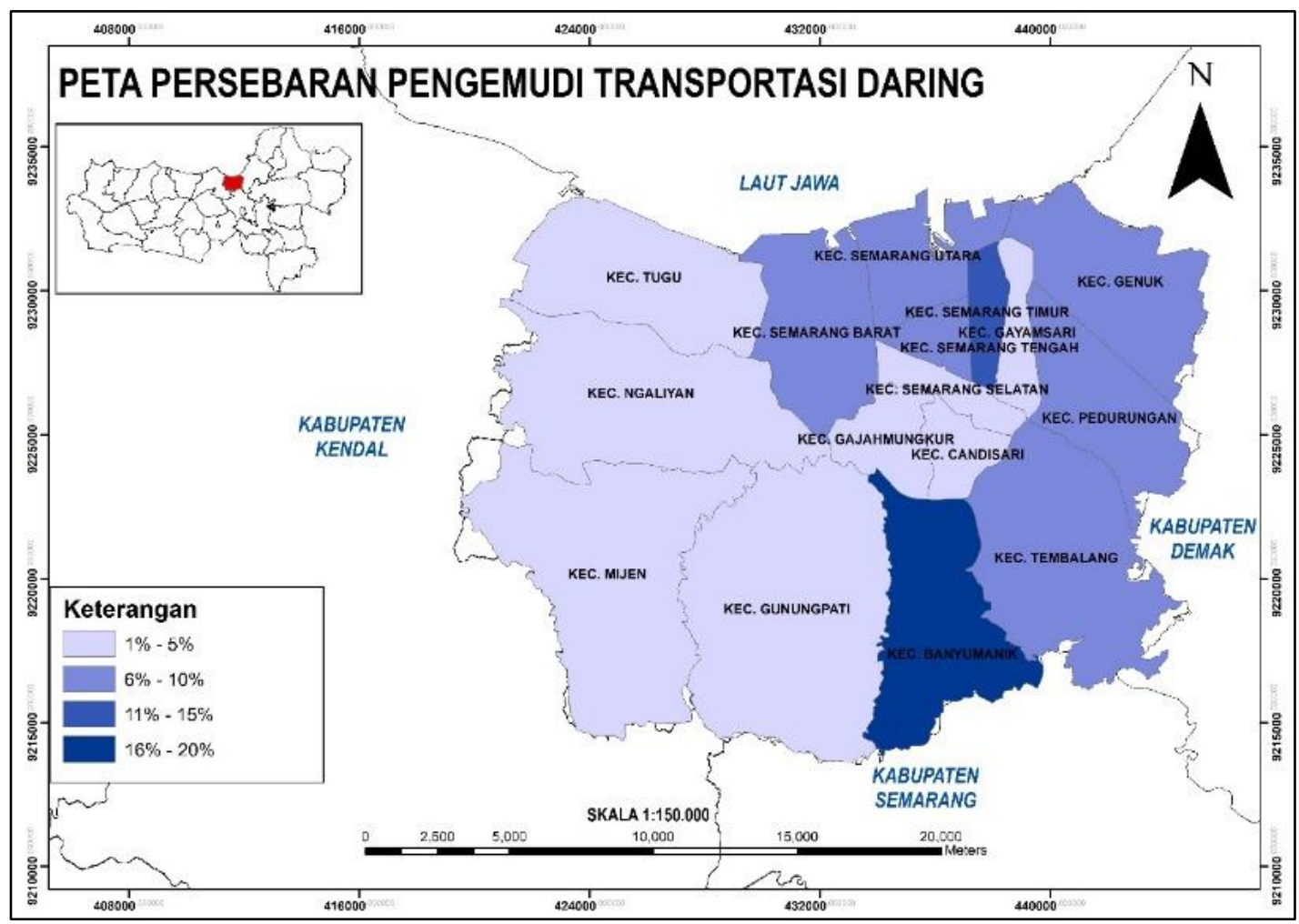

Gambar 5. Peta Persebaran Pengemudi Transportasi Daring Kota Semarang (Hasil Analisis, 2018) 
Peta persebaran pengemudi dengan daerah intensitas jumlah pengemudi tinggi membentuk pola tertentu. Pola tersebut mengalami penebalan pada bagian utara kota kemudian menyebar ke bagian timur hingga bagian selatan. Hal ini berhubungan dengan guna lahan pada daerah tersebut yang didominasi oleh lahan permukiman. Selain itu pada daerah-daerah yang memiliki intensitas jumlah pengemudi tinggi, cenderung memiliki jumlah penduduk usia kerja yang tinggi. Kecamatan yang memiliki jumlah penduduk usia kerja tinggi akan banyak memiliki pengemudi transportasi daring yang lebih banyak. Terlihat kecamatan yang memiliki jumlah usia kerja rendah akan memiliki jumlah pengemudi yang rendah. Hanya terdapat perbedaan pada Kecamatan Banyumanik dan Kecamatan Semarang Timur yang memiliki jumlah usia kerja rendah dengan jumlah pengemudi yang tinggi.Akan tetapi berdasarkan kecenderungan ini, dapat disimpulkan bahwa persebaran pengemudi transportasi daring ditentukan oleh jumlah penduduk usia kerja yang terdapat pada wilayah tersebut.

Pengemudi transportasi daring pergi dari daerah tempat tinggal untuk mencari penumpang transportasi daring. Pengemudi transportasi daring akan pergi ke daerah-daerah yang memiliki potensi ekonomi tinggi. Hal ini dikarenakan pada daerah dengan potensi ekonomi tinggi tersebut pengemudi transportasi daring akan lebih banyak mendapatkan pengguna dan mendapatkan pendapatan yang lebih banyak dibandingan dengan daerah tempat tinggal pengemudi. Semakin banyak sebuah daerah terdapat pengemudi yang mencari penumpang maka akan semakin tinggi potensi ekonomi yang dimiliki oleh daerah tersebut. Selengkapnya lihat Gambar 6.

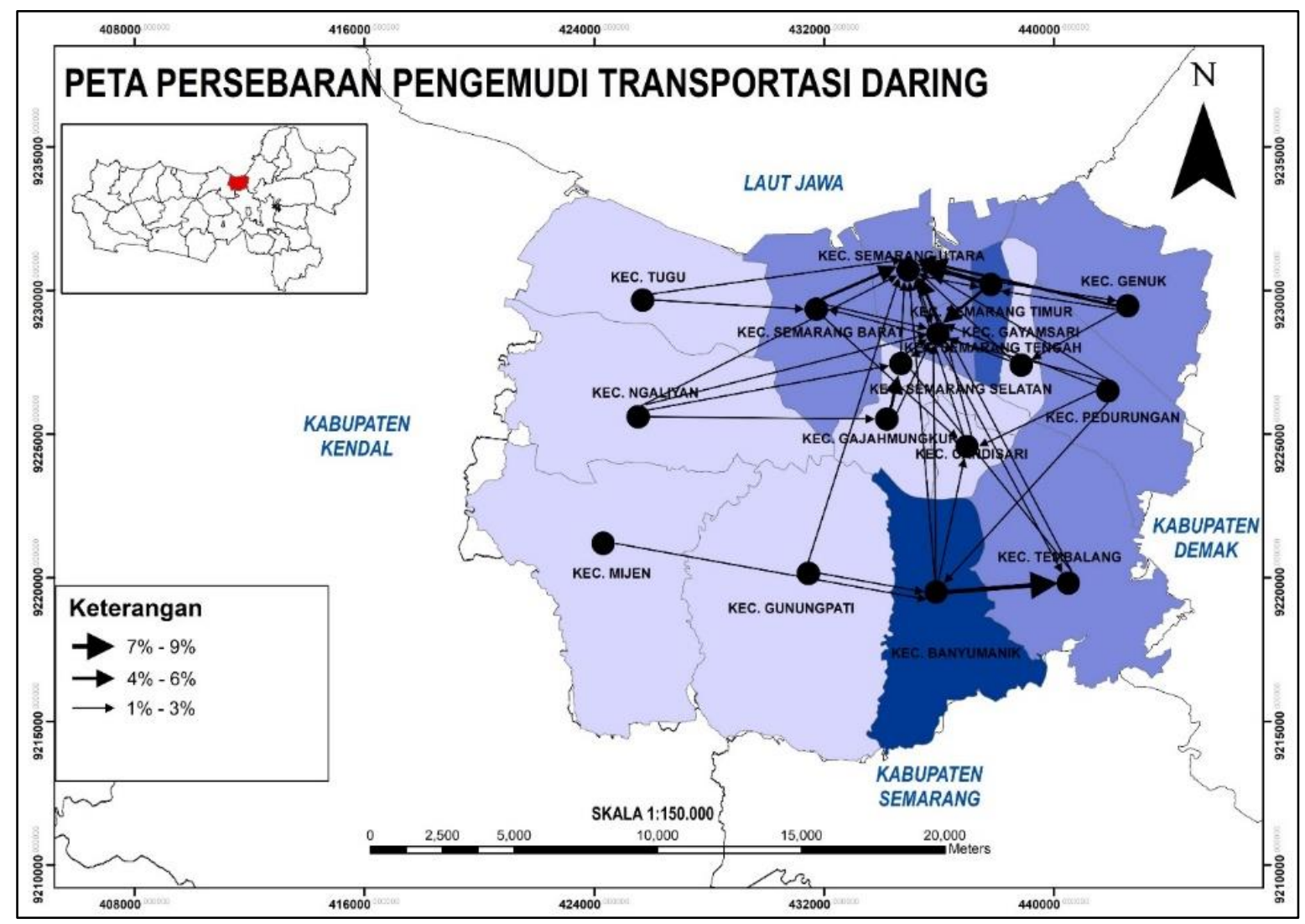

Gambar 6.Peta Peta Tujuan Pengemudi Transportasi Daring (Hasil Analisis, 2016)

Berdasarkan Gambar 6., terlihat bahwa daerah yang terbanyak menjadi tujuan pengemudi transportasi daring yaitu Kecamatan Semarang Utara, Semarang Tengah, dan Tembalang. Ketiga kecamatan tersebut memimiliki potensi ekonomi yang tinggi. Kecamatan Semarang Utara memiliki titik transit transportasi dan daerah wisata yaitu Kota Lama Semarang. Kecamatan Semarang Tengah menjadi daerah pusat kota yang didalamnya terdapat pusat perbelanjaan yaitu kawasan segitiga emas Kota 
Semarang dan daerah perkantoran. Sedangkan Kecamatan Tembalang menjadi daerah yang banyak menjadi tujuan pengemudi transportasi daring dikarenakan pada Kecamatan Tembalang terdapat kampus UNDIP. Sehingga dapat disimpulkan bahwa pada ketiga kecamatan tersebut akan memberikan pendapatan yang banyak kepada pengemudi transportasi daring dibandingkan dengan daerah lainnya di Kota Semarang.

\section{KESIMPULAN}

Transportasi daring memberikan dampak kecil terhadap penyerapan tenaga kerja dan dapat dikatakan belum berhasil menyerap tenaga kerja di Kota Semarang.Kehadiran transportasi daring di Kota Semarang menyerap $2 \%$ tenaga kerja yang sebelumnya tidak bekerja.Penyerapan yang terjadi disini berasal dari tenaga kerja yang telah memiliki pekerjaan dan beralih profesi menjadi pengemudi transportasi daring.Pada sisi tren penyerapan tenaga kerja, melihatkan bahwa tren yang meningkat setiap bulannya.Hal ini menunjukkan bahwa profesi menjadi pengemudi transportasi daring diminati oleh masyarakat Kota Semarang.Penyerapan tenaga kerja terjadi pada penduduk yang belum memiliki lapangan pekerjaan dan penduduk yang telah memiliki lapangan pekerjaan.Tenaga kerja yang terserap sebagai pengemudi transportasi daring didominasi oleh kelompok umur usia muda berkisar antara 20-30 tahun. Dominasi kelompok usia muda yang menjadi pengemudi transportasi daring berkaitan dengan kemampuan penggunaan gadget. Alasan pemilihan menjadi profesi pengemudi transportasi daring yaitu waktu kerja yang fleksibel,mencari penghasilan tambahan dan memiliki penghasilan yang besar. Sebagian besar tenaga kerja yang terserap oleh transportasi daring memiliki latar belakang pendidikan terakhir pada tingkat SMA/SMK. Selain itu tenaga kerja yang terserap ini juga terdapat pengemudi yang memiliki latar belakang pendidikan terakhir pada tingkat Diploma, Sarjana, dan Magister.

\section{PERNYATAAN RESMI}

Penelitian ini didukung dengan dana dari Fakultas Teknik Universitas Diponegoro melalui hibah Penelitian Dasar Tahun 2018.

\section{REFERENSI}

Amey, A., Attanucci, J., \& Mishalani, R. 2011. Real-Time Ridesharing: Opportunities and Challenges in Using Mobile Phone Technology to Improve Rideshare Services. Transportation Research Record: Journal of the Transportation Research Board, 2217(1), 103-110. https://doi.org/10.3141/2217-13

Asmara, N. 2017.Analisis Faktor-Faktor yang Mempengaruhi Kesejahteraan Tenaga Kerja (Studi Kasus Pada Industri Cireng Crispy Shaza di Bojongsari Depok). Universitas Islam Negeri Syarif Hidayatullah Jakarta

Delle Site, P., Filippi, F. and Giustiniani, G. (2011) 'Users' preferences towards innovative and conventional public transport', in Procedia - Social and Behavioral Sciences. doi: 10.1016/j.sbspro.2011.08.099.

Diah Intan, Anita Ratnasari, A. (2018) 'Mapping Between Bus Rapid Transit Shelter and High School Location in Semarang Mapping Between Bus Rapid Transit Shelter and High School Location in Semarang', Science, Environmental. doi: 10.1088/1755-1315/123/1/012013.

Grazia Speranza, M. 2016. Trends in Transportation and Logistics. European Journal of Operational Research. https://doi.org/10.1016/j.ejor.2016.08.032.

Hall, J. V, \& Krueger, A. B. 2016. An Analysis of the Labor Market for Uber's Driver Partners in the United States. Cambridge: National Bureau of Economic Research.

Handoyo. R.D. 2005. Ekonomi Sumber Daya Manusia. Modul 1, Hal 1-37.

Henao, A., Marshall, W. 2017. A Framework for Understanding the Impacts of Ridesourcing on Transportation. Denver: Springer International Publishing.

Kadir, A. (2006) 'Tranportasi : Peran dan Dampaknya Dalam Pertumbuhan Ekonomi Nasional', Jurnal 
Perencanaan dan Pengembangan Wilayah Wahana Hijau, 1(3), pp. 121-131.

Lyons, G. and Davidson, C. (2016) 'Guidance for transport planning and policymaking in the face of an uncertain future', Transportation Research Part A: Policy and Practice. doi: 10.1016/j.tra.2016.03.012.

Paronda, A. G. A., Regido, J. R. F., \& Napalang, M. S. G. 2016. Comparative Analysis of Transportation Network Companies ( TNCs ) and Conventional Taxi Services in Metro Manila. 23rd Annual Conference of the Transportation, (August), 1-12. Retrieved from https://s3.amazonaws.com/academia.edu.documents/54055483/Comparative_Analysis_Uber_G rab_Taxi_Paper_Paronda_2_FINAL-rev-

06302016.pdf?AWSAccessKeyld=AKIAIWOWYYGZ2Y53UL3A\&Expires $=1517457700 \&$ Signature $=K$ Vlw86klvqMeM34kwPCSdDjoxLc\%3D\&response-content-dispositio.

Rakhmatulloh, A. R. et al. (2018) 'What is the Role of Land Value in the Urban Corridor?', IOP Conference Series: Earth and Environmental Science, 123(1). doi: 10.1088/1755-1315/123/1/012033.

Safrino, A. 2017. Efisiensi dan Dampak Ojek Online Terhadap Kesempatan Kerja dan Kesejahteraan. Institut Pertanian Bogor. Retrieved from http://repository.ipb.ac.id/jspui/bitstream/123456789/87593/1/H17asy.pdf.

Simonyi, E., Fazekas, Z., \& Gáspár, P. 2014. Smartphone application for assessing various aspects of Urban public transport. In Transportation Research Procedia. https://doi.org/10.1016/j.trpro.2014.10.104.

Siuhi, S. and Mwakalonge, J. (2016) 'Opportunities and challenges of smart mobile applications in transportation', Journal of Traffic and Transportation Engineering (English Edition). doi: 10.1016/j.jtte.2016.11.001.

Stalmašeková, N., Genzorová, T., Čorejová, T., \& Gašperová, L. (2017). The Impact of Using the Digital Environment in Transport. In Procedia Engineering. https://doi.org/10.1016/j.proeng.2017.06.040.

Wallsten, S. 2015. The Competitive Effects of the Sharing Economy: How is Uber Changing Taxis?. Technological Policy Institute, (June), 1-22. Retrieved from www.researchgate.net/publication/279514652_The_Competitive_Effects_of_the_Sharing_Econ omy. 